\title{
Managing the Urban Environment of Istanbul, Turkey
}

\author{
David J. Edelman \\ School of Planning, College of Design, Architecture, Art and Planning, University of Cincinnati, Ohio, USA \\ Email: edelmadj@ucmail.uc.edu
}

How to cite this paper: Edelman, D. J. (2021). Managing the Urban Environment of Istanbul, Turkey. Current Urban Studies, 9, 107-125.

https://doi.org/10.4236/cus.2021.91007

Received: January 7, 2021

Accepted: March 7, 2021

Published: March 10, 2021

Copyright $\odot 2021$ by author(s) and Scientific Research Publishing Inc. This work is licensed under the Creative Commons Attribution International License (CC BY 4.0).

http://creativecommons.org/licenses/by/4.0/

\begin{abstract}
This article brings the contemporary thinking and practice of Urban Environmental Management (UEM) to the solution of current environmental problems in Istanbul, Turkey. With a fast-growing population of over 15 million, Istanbul is both the largest city in Europe and the world's $5^{\text {th }}$ largest city in terms of population within city limits. Such cities face more immediate problems than those in the developed world and have fewer resources to deal with them. The article first considers the context of Turkey, and then reviews issues of poverty alleviation, industry, transportation, energy, water, sewage and sanitation, and finance. Finally, it proposes a 5-year plan to help alleviate the urban environmental problems of this transcontinental city utilizing a real-world database compiled from Turkish government documents and a limited budget.
\end{abstract}

\section{Keywords}

Urban Environmental Management, UEM, City and Regional Planning

\section{Introduction}

Urban Environmental Management (UEM) has been receiving increasing attention since 1970 in both developed countries, where it has emerged as a subject of academic research and professional interest, and in developing countries, where it has become increasingly an area of donor concern as well. As a field, it is more like planning or engineering rather than geography, economics or sociology; and it represents an integrated view of environmental problems at city, and increasingly, regional level. Such problems are multi-sectoral (e.g., manufacturing, services, household, etc.), multi-system (e.g., water supply, sanitation, transport, etc.), multi-level (central, regional, local and community) and multi-actor (e.g., government, $\mathrm{NGO}, \mathrm{CBO}$ and private). They require solutions of enormous 
complexity, and those professionals who coordinate the planning, implementation and management of the process must be able to communicate with specialists from many disciplines and professions (e.g., biology, chemistry, engineering, city planning, public administration, social sciences and law) (Edelman, Schuster, \& Said, 2017).

This article focuses on the practice of Urban Environmental Management in developing countries which face more immediate problems than the developed world and have fewer resources to cope with them. It summarizes the findings of a graduate-level workshop that took place at the School of Planning, College of Design, Architecture, Art and Planning, University of Cincinnati, USA from August through December 2020. The objective of the workshop was to prepare students to work overseas in data-poor environments as professional consulting planners. Several lectures were given to set the framework of the mixed class of 10 domestic and international students to operate in seven collaborative sector-level working groups or teams preparing a 5-year Environmental Plan for Metropolitan Istanbul, Turkey utilizing a real-world database and a limited budget. Istanbul is the cultural, economic, and commercial heart, as well as the largest city, of the world's $17^{\text {th }}$ most populous country. With an estimated 2020 population of 84.625 million

(https://www.worldpopulationreview.com/countries/turkey-population), Turkey is one of the world's most populous majority Moslem countries. It is also extremely important geopolitically as it is located at the nexus of Europe, Asia, and the Middle East. Istanbul is a historic global city with deep roots in both Christianity and Islam. It has been one of the world's largest cities for most of its history and in $500 \mathrm{AD}$ passed Rome as the largest city in the world at that time (https://www.worldpopulationreview.com/world-cities/istanbul-population).

With its population now over 15 million, Istanbul is one of the largest agglomerations in Europe and the $5^{\text {th }}$ largest city in the world in terms of population within city limits (Ibid.). A transcontinental city located on the Bosphorus Strait in northwest Turkey between the Black Sea and the Sea of Marmara, Istanbul's commercial center is in Europe while the rest of the city lies in Asia.

Istanbul experienced especially rapid growth during the second half of the 20th century, with its population increasing tenfold between 1950 and 2000. This growth in population comes, in part, from an expansion of city limits particularly between 1980 and 1985, when the number of Istanbul's residents nearly doubled. The remarkable growth was, and still is, largely fueled by migrants from eastern Turkey seeking employment and improved living conditions. The number of residents of Istanbul originating from seven northern and eastern provinces is greater than the populations of their entire respective provinces! Istanbul's foreign population, by comparison, is very small, 42,228 residents in 2007. Only $28 \%$ of the city's residents are originally from Istanbul (Ibid.). The most densely populated areas tend to lie to the northwest, west, and southwest of the city center, on the European side; the most densely populated district on the Asian side 
is Üsküdar (Ibid.).

Moreover, Istanbul's urban plans have not been able to control or to manage the growth of the city. Nearly $60 \%$ of development is unplanned, unauthorized, low cost and incremental, and more than $60 \%$ of the present building stock is unsafe and low quality (Türkoğlu, 2020). Unfortunately, according to the 2006 plan of Istanbul, if the present trend is not controlled, the population in 2020 may reach 20 million people, while according to sustainable development principles, the capacity of developable land is 16 to 17 million people (Ibid).

\section{Poverty Alleviation}

Nevertheless, Istanbul has been working to reduce the effects of poverty in the country and has made progress. According to David Jacques who has shared information on the Borgen Project website, "the number of people living below the poverty line in Istanbul has never been smaller. Over the past 10 years, the share of the population living on less than $\$ 4$ a day has fallen from more than 20 million to just 1.7 million" (Jacques, 2019). Turkey has been a pioneer in finding ways to alleviate poverty. The economic situation for Turkey has been improving, but factors like the Syrian refugee crisis and urban-rural divide complicate it. Turkey seems to have already started to find ways to tackle the barriers that make up poverty, but these lingering concerns remain issues on a macro scale that need to be fixed over time. Yet placemaking can be a way to address some of the issues related to poverty on a micro scale.

Creative placemaking through small interventions can enable a community to grow and improve over time, allowing for residents to come together and tackle the disparities they may have in their neighborhoods. Start-ups can arise at the grass roots level with the interventions becoming a part of a lifelong learning process that can impact communities. These are possible ways to address some of the needs that under-resourced communities may face on a typical daily basis, but by introducing these, there may be room to allow for those residents in the community to create and open doors for themselves and others if they are willing and open to that possibility (Edelman, 2021).

Pilot studies that explore these interventions are suggested for Sultanbeyli, a well-known unauthorized district on the fringe of Istanbul with a high population of Syrian refugees. Possible ways to address issues in impoverished communities through the implementation of spaces like these can be interventions such as a community garden; mobile library and school; and micro, ad-hoc, or mobile shelter, all of which can alleviate the distractions of drugs and other safety and communal concerns. These spaces can be ephemeral in their nature but can alleviate issues through their existence.

\subsection{Community Garden}

A community garden is a public space that can help foster relationships within a community and create a place of accountability and responsibility. Over 
time, it could be used as a way to introduce fresh food to a community while also teaching about gardening. In addition, there may be an opportunity for a water reclamation system to capture rainwater, an initiative to keep the immediate area clean and reduce wastage as well as over time becoming a space where people can come to learn, read and use other resources that may be proposed. According to TRUiC's webpage on How to Start a Community Garden, "A community garden's startup costs are between $\$ 3750$ and $\$ 7500$. Costs include establishing the garden near a source of water, maintaining city fees, insurance and contractor wages. A large community garden can even cost as much as $\$ 30,000$ ” (TRUiC, 2020).

\subsection{Mobile Library}

Poor education is one of the most significant outcomes of poverty within any country or community. Limited access to resources creates an environment where those impacted may not have a substantial basis of being educated or literate. "There are currently programs within Istanbul that are focusing on this problem such as ACEV, which are in place to help teach literacy to children and mothers. To date they are noted to have helped over 100,000 people" (Jacques, 2019). With so many organizations that are investing in educating families, especially children, in Turkey, there may be a grassroots approach to this process that can allow for outreach and can be applied through placemaking. For a Sultanbeyli pilot project, the solutions that seem appropriate and affordable are the outreach bike and the library station. Smaller than a bookmobile, the outreach bike can be an attachment to the back of a bike that has a collection of books, a Wi-Fi hotspot or some sort of service that allows for the users to engage with the library on a smaller scale. Owing to the outreach being limited to the physical capability of the biker; this model suits the city or its urban fringe. The library station, however, does not serve as a mobile unit but instead, is a stationary structure placed within a community or area that allows for the residents to take a book or leave a book. A possible structure for this could be for the library to drop off new books on a consistent schedule so the choices to select from vary. This outreach allows the library to interact with members of the community it may not traditionally reach.

\subsection{Ad Hoc Housing}

The ability to place-make can be useful when thinking about housing as well. From using existing structures to lightweight temporary units, housing can help address poverty through a series of micro homes, pop-up shelters and mobile units. Homelessness is an issue that stems from poverty, and the use of pop-up shelter and housing can help address that issue. This intervention can start with an organization providing tents or affordable small footprint models to address immediately the issue and over time work towards creating or designing spaces that can provide shelter. Another possible solution to housing can be to utilize 
existing structures providing the tools and resources for someone to erect a home within this structure without having to demolish the existing framework or the building. The estimated cost for this immediate pop-up housing can start as low as $\$ 30,000$ but can be greater than $\$ 150,000$. Maintenance and utilities would be additional incurred costs.

\subsection{COVID-19 and Pop-Up Health Care}

COVID-19 has impacted the economies of countries worldwide and led to many businesses, companies and institutions shutting down due to a lack of funding. Turkey is no different, and this has caused a lot of people to face poverty and struggle for their livelihood while it has also set back many poverty alleviation initiatives. A major current concern is the lack of access to proper healthcare and facilities. Living in poverty can mean that if exposed to or coming in close contact with someone who is carrying the disease, reasonable diagnosis and treatment for that patient may not be available. Those with underlying conditions could possibly be impacted more by the disease. There are numerous pop-up test sites placed everywhere, and if this same logic is applied to those hard-to-reach areas or emphasis is placed on the lower income communities, then this would solve the problem of their lack of access to healthcare through pop-up spaces.

\subsection{Conclusion}

Although the proposed interventions outlined above explore the potential for a series of pilot projects to be established in one of the city's communities (Sultanbeyli) as a part of a 5-Year Environmental Plan for Istanbul, there are additional potential sites in the city for the placement and addition of these ad-hoc spaces should the pilot projects be successful. These areas are Sahintepe, Sultangeyzi, Karayollari, Bahcelievlier, Zeytinburnu, Tarlabasi, Kagithane, Hasapansa and Basibuyuk.

Engaging with community members early on and creating relationships can allow for the residents to establish roles and community leaders who may be the voice of the residents when the time comes for these interventions to be implemented. These leaders would be able to speak for their group of interested individuals and can then provide a more viable space for them because they know what the needs are. Over time, this can allow each intervention to be specific to the needs and desires of that certain community. Overall, each community design intervention will not look the same because their character will be based on the needs and individuals who are living there, although there may be some similar characteristics.

\section{Industry}

\subsection{Structure of the Sector}

In Istanbul, the industrial sector is led by automobile production, followed by textiles and apparel. Multi-industry manufacturers, which include electronics 
and home goods, are important as well, but their contribution to the Istanbul economy is less significant. In 2018, Turkey's auto production was ranked $15^{\text {th }}$ in the world (Güven, 2017). Turkey not only manufactures automobiles, but the country's automotive market also includes research and development centers staffed with highly qualified mechanical engineers.

Electric vehicle development and production is seen as an important government initiative. President Tayyip Erdoğan hopes that by improving the electric domestic vehicle, the car would both sell at home and become a global brand in Europe. The project was launched in October of 2019, and the government has promised it will receive state support such as tax breaks. Production is expected to begin in 2022 .

The textile industry was one of the first industries established in Turkey. Today, however, the textile industry is the $2^{\text {nd }}$ largest, after the automotive industry. The fabric industry is a sub-sector of the textile industry, and it has improved significantly. One of the reasons is that many raw materials are now domestic. Turkey, for example, is ranked $8^{\text {th }}$ in the world production of cotton (Erai Turkey, 2020).

Multi-industry manufacturers, such as Zorlu, Vestel, Beko and Arçelik A.Ş, are essential companies that offer electronics, household appliances and mobile technologies. Beko is a Turkish appliance and consumer electronics brand of Arçelik A.Ş. It is the first Turkish white goods brand to be sold abroad, and its long-term goal is to become a world brand (Zorlu Holding, n.d.).

\subsection{Proposed Projects}

Given Turkey's relatively advanced industrial sector, the projects proposed here for the 5-Year Environmental Plan for Istanbul include:

\section{- The production of fuel-efficient automobiles}

As a result of ongoing research and development in the automotive sector, it is assumed that new vehicles produced in the period of the plan will be $10 \%-15 \%$ more energy efficient than the vehicles they replace. This is a transition step while electric vehicles become cheaper and more widely used enabling a transition to an all-electric fleet within 20 years.

\section{- The production of electric cars}

This will be a collaboration of several companies starting with researching existing automotive facilities in Istanbul. Each of 5 companies will invest 19\% in electric vehicle development and production; they are expected to be: Anadolu Group, BMC, Kok Group, mobile phone operator Turkcell, and Zorlu Holding. Investors will provide at least TYL3.5 billion in cash as capital (Bilgic, 2019).

- Textile and Apparel

Investments will be made in growing more cotton and building a state-of-the-art production facility to increase production of cotton, yarn and woven fabrics, while raw materials will also be acquired to produce ready-made apparel, i.e., T-shirts, men's and women's non-knit suits, sweaters, pullovers, sweatshirts, etc. 
Istanbul is an ancient city with a glorious history and culture, but many current challenges. As the largest and most important metropolitan area of Turkey, which is an emerging industrial power, there are many opportunities ahead. Although the development and production of electric cars will receive significant government support, all of the projects suggested above will largely be funded by private Turkish investment. However, to maximize the value of the sector for its citizens, it must confront the environmental issues it faces. The industrial projects suggested here are all contribution to that end.

\section{Energy}

Like other large, dynamic developing nations globally, such as Brazil, Nigeria, India and China, the demand for energy is steadily growing in Turkey. As its most populated and expansive metropolitan center, Istanbul contributes greatly to this demand. Enerdata, a company that studies global energy, details consumption statistics for the country in its online interactive page. It states, "Total energy consumption has been stable since 2017 at around 147 Mtoe" (Enerdata, 2020). Accessed 4 December 2020 at

https://www.enerdata.net/estore/energy-market/turkey.html. However, Istanbul is the country's highest consumer of electricity.

The annual electricity consumption of Istanbul, with 4.3 million subscribers on the European side and 2.6 million on the Anatolian side, reaches 33.5 billion kilowatts per hour. Turkey is in the top-20 highest electricity consuming countries, and Istanbul's consumption is within the top-50 cities with the highest electricity consumption (Daily Sabah, 2014).

Generating the large amount of power for Istanbul and the rest of Turkey causes vast amounts of nonrenewable energy sources to be burned and released into the atmosphere. Coal, natural gas and oil are the primary sources for the nation as a whole, as well as Istanbul. On average over the last decade, coal, natural gas and oil have supplied $85 \%$ - $95 \%$ of energy for the country, and they have largely been imported. Fully renewable sources such as wind, solar or geothermal exist as a minute sliver of the total energy supply for Turkey, even though the country exhibits massive potential for them (IEA, 2020). In fact, Turkey ranks $16^{\text {th }}$ in the EY Renewable Energy Country Attractiveness Index (Renewable Energy Development of Turkey, n.d.). Accessed 4 December 2020 at https://conexioenergy.com/renewable-energy-development-of-turkey/.

While Turkey's energy issues may seem irreversible, smaller scale solutions for its cities can exhibit measurable successes that can be scaled up. The solution proposed here that fits within the 5-Year Environmental Plan for Istanbul is called Istanbul Solar Infill. Based on a network of solar farms, the project will serve both Istanbul and Turkey to signal that they can utilize resources within the country to create an affordable renewable energy solution. Funding for the project will come from a combination of sources, but most prominently, the central government. Private companies and investors will receive tax benefits 
from participating in this project and similar projects in the future. The more land they are willing to supply for solar arrays, the larger the tax break they will receive. As years pass and the solar facilities begin to turn a profit in Istanbul, the hope is that they will continue to grow and form a network of solar arrays across the country. This proposed approach and project fit within the larger goals of the Ministry of Energy and Natural Resources. If Istanbul strives to be more renewable in its energy consumption, this project can hopefully serve as a spark to more projects in the city and across the nation. As mentioned above, Turkey could be fully powered by the solar potential within its borders (Renewable Energy Development of Turkey, n.d.); the country just needs to break ground on projects that illustrate that the benefits outweigh the costs. The Istanbul Solar Infill project stands as one of those opportunities.

\section{Transportation}

\subsection{Background}

Istanbul has a comprehensive and incredibly complex transport system that uses almost all recognized modes of public transportation. Within the city limits, one can travel by bus, Dolmus (a kind of group taxi), commuter train, suburban train, tram, cable car, ferry, fast ferry, sea bus and sea taxi, as well as bike sharing, carpooling and private car (TripAdvisor, 2020).

The Bosphorus Strait not only separates Europe and Asia, but it is one of the busiest waterways in the world (The Times Tribune, 1974). The strait is crossed by large ocean-going vessels, and countless smaller ferry boats navigate it, bringing commuters from one continent to another. The city's layout, dating back to the Ottoman period, is not well suited to the traffic of a large metropolis. $65 \%$ of the residents of Istanbul live on the European side, and 25\% live on the Asian side; which means many travel back and forth several times a day (Films Media Group, 2013). Nevertheless, in recent decades, Istanbul's modal division has shifted in favor of the automobile (Hennig, 2011). There are three bridges across the Bosphorus and two tunnels, although the 28-mile-long Canal Istanbul is intended to restrict this traffic across the strait and offer an alternate seaway for ships (Courrier International, 2020). Canal Istanbul: New Landmark Project of Turkey

(https://eraiturkey.com/news/canal-istanbul-new-landmark-project-of-turkey/).

Issues in the transportation sector are administrative overlap, a politics driven approach, traffic congestion, issues related to sustainability and modal integration. The solutions suggested here include a number of solutions over the short-term (within 1 to 5 years), medium-term (within 6 to 10 years, and long-term (within 11 to 20 years). The short-term solutions, which fit within the timeframe of the environmental plan discussed in this article, include forming a task force to discuss administrative issues, integration issues and budget priorities; and preparing a report on identification of congested areas and traffic decongestion strategies. These would form the basis for the mid- and long-term 
projects.

\subsection{Short-Term Initiatives}

- Form a Task Force to Discuss Administrative Issues, Integration Issues and Budget Priorities. One of the major problems in Istanbul's transportation sector is the lack of a responsible authority and the lack of coordination for solving transportation issues. The proposed solution to this problem would be the formation of a task force, which has members from different backgrounds related to transportation. It should include planners, representatives from different transportation management and implementation agencies, lawyers, financial experts and citizen elected representatives. This taskforce would discuss issues related to transportation administration, the hierarchy of different organizations and their roles, integration of different modes of transportation, planning and implementation, sources of funding and budget priorities.

- Istanbulkart is a smart card used for fare payment on public transport in Istanbul. However, it covers only certain modes of transportation, i.e., buses, funiculars, LRT, subway, commuter trains, ferryboats and trams operated by the Metropolitan Municipality and private companies. As part of the integration issue, integration of transfer fees to certain other modes of transportation such as dolmuses, minibuses, taxis, etc. would be discussed. If approved by a majority of members, it would be implemented.

- A new bicycle app can encourage citizens to embrace the cycling culture. This app can have characteristics of some interesting apps like Lanespotter and BikeCitizens. The app can have features such as new cycle routes, bike lanes and trails in the area, journey records of people, news on cycling, bicycle campaigns and events. The app can also have a Safety Map through which users can create and view ratings for any road from "very safe" to "avoid," and an Alert Map through which users can raise problems like road closures or heavy traffic in real-time. The app will also show the bikeshare stations. It can be promoted through public interest advertisements on television, in movie theatres, on social media platforms, and through posters on public vehicles. This app is envisioned to be created through a public-private partnership (BikePGH, 2018; Bike Cleveland, 2018).

\section{Encourage citizen engagement for transportation projects.}

The transportation projects in Istanbul, and, for that matter, in most cities around the world, are politically driven, and public consensus is not given much importance. Projects like Canal Istanbul might be beneficial to people who have power, but they are harmful for the environment and face opposition from citizens. Unfortunately, the fate of these projects is not in the hands of the citizens. Some cities in the world are moving towards creating a digital platform where transportation projects are introduced to the people, and public input is obtained. Neighborland, CitizenLab and Delib are examples of citizen engagement 
companies, which provide their services to different cities, states, national governments, and to different authorities, associations and nonprofits across the world. Istanbul can collaborate with one of the 3 companies, especially CitizenLab, which serves northern Europe, Canada and Chile; and Delib, which serves the UK, Australia and New Zealand. Through these companies, Istanbul can have a new platform for displaying potential transportation projects, and citizens can vote, fill surveys and express their opinions regarding the projects officially. This website can also provide information about online or in-person public meetings.

$>$ Prepare a Report on Identification of Congested Areas and Traffic Decongestion Strategies.

According to statistics provided by the Istanbul Provincial Directorate of Culture and Tourism, the megacity hosted 13.4 million foreign tourists in the last year. While the largest proportion of visitors were from Germany and accounted for around 1.07 million visitors, tourists from Iran, Saudi Arabia, Russia, Iraq, the UK, France and the U.S. were also among those at the top of the list (İstanbul Ticaret Gazetesi, 2020). As a consequence, the popular tourist areas in the city are highly congested.

A study for the pedestrianization of streets has already been conducted for the Historical Peninsula area, and projects to create pedestrianized streets are now ongoing in this area. It is expected that 295 streets will be pedestrianized (Istanbul Metropolitan Municipality, 2018). Annual Report 2018

(https://www.ibb.istanbul/en/SitePage/Index/212). Similar studies need to be conducted in the other 4 tourist areas of Istanbul, and important streets and spots need to be identified to reduce congestion and promote walkability.

\subsection{Summary}

Istanbul, a city with numerous transportation modes, is facing many issues related to congestion, integration of those modes, administration and organization, political influence on transportation planning, lack of sustainable modes, and a lack of awareness about sustainable and eco-friendly transportation. Through a wide range of solutions, the aim is to either alleviate or completely overcome the issues mentioned. The proposals involve creating completely new solutions or adding to the existing efforts being taken. The short-term initiatives (1 - 5 years) involve forming task forces to discuss different issues, conducting studies and providing reports on traffic congestion, and creating apps and websites for awareness and community engagement. The mid-term initiatives (6 - 10 years) focus on implementing traffic congestion strategies and creating an app for integration of various modes. The long-term initiatives (11 - 20 years) are more about creating transit hubs, interlinking multi-modal transport services, and creating charging stations for electric buses, which will be introduced in Istanbul over a period of 20 years. This 20 -year plan envisions Istanbul to become a city with reduced congestion, systematic and sustainable transportation, easier travel 
due to integration, and a city where public input and community engagement will be a priority.

\section{Sewage and Sanitation}

\subsection{Current Conditions}

Like many major metropolitan cities in developing countries, Istanbul faces a sewage and sanitation services dilemma. Prior to modernization efforts, sewage and sanitation wastes were disposed of in bodies of water, open dumps, landfills and incinerators (Nas \& Bayram, 2008). Sewage and sanitation services are better today, but more should be done to take advantage of new technologies and make additions to meet future needs.

A quick review of existing sewage and sanitation conditions reveals that Istanbul generates a lot of waste. That is certainly no surprise; managing sanitation presents a challenge for cities like Istanbul (Berkun, Aras, \& Nemlioglu, 2005). As Istanbul's population continues to grow, the effects of sewage and sanitation challenges expand too. With a 2019 population of 15,519,267 people, Istanbul generates over 28.9 million tons of waste (TURKSTAT, 2019)

(https://www.tuik.gov.tr/).

Istanbul is not only a very large metropolitan city, but it has one of the most rapidly growing populations in Europe. With an annual population growth rate of $2.8 \%$, this growth is almost twice the overall rate of Turkey as a whole (van Leeuwen \& Sjerps, 2016). The future of Istanbul's success lies in fixing its problems. Based on the current state of Istanbul's sewage infrastructure, policies and finances, there is a need for improvements. It is recommended that Istanbul develop a sustainable and efficient system by upgrading technology, replacing pipelines, and creating new policies.

\subsection{Sewage Recommendations}

The first sewage recommendation for Istanbul is sewage pipeline replacement, which is estimated to cost $\$ 3$ million. By replacing sewer pipelines and upgrading to advanced biological systems, fringe districts will have the ability to obtain clean water. Municipal wastewater infrastructure in Istanbul has not been as well developed as the water supply system, but the sanitary sewer system is, nonetheless, quite significant.

The second recommendation for Istanbul is installation of Membrane Bioreactor (MBR) technology into existing wastewater treatment plants. Membrane bioreactors for wastewater treatment is a suspended growth biological method using activated sludge, with membrane filtration equipment. The membranes perform the critical solid and liquid separation. Upgrading plants with this new technology can be costly, but this is changing. Investment costs are decreasing and the cost effectiveness of MBR is expected to improve in the future. Moreover, the MBR footprint is $40 \%-60 \%$ lower than that of classical treatment technologies, reducing land costs (Iglesias et al., 2017). Nevertheless, at present, this 
is expected to cost about $\$ 369,000$ to upgrade each wastewater treatment plant.

\subsection{Sanitation Recommendations}

As far as sanitation is concerned, the first recommendation involves conducting a waste composition study to get a clear picture of the types and quantities of items in the waste stream. A solid waste type study examines municipal waste types, construction wastes, special waste, and other waste details as needed. Its estimated cost is $\$ 150,000$. A thorough examination of the waste facility inventory can provide valuable information about the: number and types of sanitary landfills that are available, the number of open dumps that exist, transfer stations, gas-to-energy plants, waste incinerator facilities, composting facilities and recycling facilities. Obtaining these pieces of information will help complete planning and budgeting details in future phases of the project.

The second recommendation is to expand the Trash for Transit Credit Program (i.e., exchanging plastic bottles for public transit coupons), which would also cost about $\$ 150,000$, while the third is to improve the Trash Collections System/Trash Pickers Program (i.e., helping waste pickers with carts, etc. to pick up and sort trash), expecting to cost $\$ 60,000$, and the fourth is to continue waste management facility improvements, which is the project with the most significant investment $(\$ 28,450,000)$. However, over the last 15 years, Turkey and Istanbul have invested money and resources into waste management activity. Despite the money, time, and legislation associated with waste management activities, more than $80 \%$ of all collected waste still gets disposed of in landfills. Building new sanitary landfills, incinerators, transfer stations and compost facilities is costly. Adding 1 or 2 new facilities every few years and modernizing old sites will keep the supply of good functioning facilities available well into the future.

The final recommendation is to expand the GIS Technology Program. Access to a dedicated MSW GIS resource will help keep accurate information on the types and locations of waste management facilities as needed. The costs associated with this proposal total $\$ 500,000$.

\section{Water}

\subsection{Introduction}

Istanbul is one of the oldest cities in the world with a history of over 8500 years, but unique to many ancient cities, it was not founded near any major freshwater resource like a lake or river (ISKI, 2020). With its huge and growing population, and the threat of drought due to the changing climate, water is a matter of serious concern.

The Istanbul Water and Sewerage Administration, or ISKI, was established in 1981 as a subsidiary of the Istanbul Metropolitan Municipality (IBB). The administration operates with a private budget, with a majority of the income com- 
ing from water sales. The administration is in charge of 3 main tasks: planning construction and operation of water supply, planning construction and operation of wastewater and stormwater drainage, and protection of surface waters including seas, lakes, rivers, as well as groundwater sources (Ozturk \& Dursun, 2015).

A city surrounded by water that is either brackish or non-potable, Istanbul is supplied primarily by surface water sources located outside of the provincial borders (Easton, 2017). Water from rainfall is collected in dams and regulators and is then supplied to the city after undergoing treatment processes. Water resource locations in Istanbul are unbalanced, with $77 \%$ of resources located on the Asian side, including the Melen System, where only 35\% of the population resides (Ozturk et al., 2017). This odd distribution does not pose a problem if water can be consistently and efficiently transported to necessary areas. Because a majority of usable water is so far away, the city has an extensive underground water network.

The 21 potable water treatment plants provide the city with around 4,352,220 $\mathrm{m}^{3} /$ day. About $134 \mathrm{~km}$ of new transmission lines were added in 2019 within the third stage scope of a current master plan project known as the Melen System, Istanbul's planned water insurance project (ISKI, 2020).

In 2014, an assessment done by Watershare, called City Blueprint, in the context of the European Innovation Partnership on Water of the European Commission, aligns with the quality and improvements that ISKI upholds for the city of Istanbul. Watershare is a global network of research organizations and utilities that applies expertise to combat water challenges (Watershare, 2020). Although City Blueprint is a baseline study and not refined or comprehensive on asset management or resource planning, it is effective and efficient in benchmarking cities with regard to the sustainability of their currently integrated water resource management and development systems. Eventually, City Blueprint aims to provide a collaborative platform that allows cities to share best water practices in the context of rising urbanization (Ibid.). For Istanbul, the overall Blue City Index score is a 5.3. To put this in perspective, 30 of the recorded cities at the time ranged between 3.5 to 8.0, and cities above 7.5 included Amsterdam, Berlin and Hamburg. Cities lower than 5 include Belem in Brazil and Dar es Salaam in Tanzania. Thus, Istanbul's score is average in comparison (ibid.).

\subsection{Issues}

However, Istanbul faces future difficulties with its water. As noted, the city's current population is $15+$ million, but it is expected to be 21 million by 2050 . Approximately 250,000 people migrate to the city annually from all over the country for opportunity or to escape political and social conflicts; furthermore, since the Syrian war, Istanbul hosts around 600,000 Syrian refugees per year. The gross water demand in the city today is around 175 liters per capita per day, but 
by 2050 this number is expected to increase to 225 (Ozturk et al., 2017).

Uncontrolled or controlled urbanization, as well as industrialization, have also led to saltwater intrusion and an increase in water pollution for all water sources in and around Istanbul. Groundwater levels have diminished in some areas, ranging from 30 meters up to 150 meters. It is common to see floating garbage, sewage, and other pollutants in the Bosphorus while walking down the street, and, as of 2012, it was categorized as one of the most active and polluted sea-straits in the world (Lehtinen, 2012).

As previously noted, the Bosphorus Strait is one of the most highly trafficked waterways in the world with over 48,000 ships passing through each year. In January of 2020, a new path for a new $45 \mathrm{~km}$ shipping canal, joining the Black Sea to the Marmara Sea, was approved. This canal project, named Canal Istanbul, was first introduced in 2011 by Turkey's President Recep Tayyip Erdoğan to reduce water traffic. The Bosphorus Strait already cuts through the middle of the city, but this new canal would run parallel disrupting precious wildlife and water supplies including the Küçükçekmece Lagoon, Sazlidere Stream and Reservoir, and Terkos Lake. Critics, including Istanbul's mayor, foresee how detrimental this costly project could be on the environment and especially Istanbul's water resources (Fox, 2020).

\subsection{Mitigating Actions}

ISKI, however, is very active. It created an Istanbul Master Plan Consortium (IMC) to create a master plan for water supply, wastewater and stormwater planning. This plan, as well as the resources that Istanbul has today, confirms that the city does not foresee any deficiencies in terms of water resources in the near future.

With a rapidly increasing population and extreme weather changes, Istanbul and the Istanbul Water and Sewerage Administration have found numerous solutions that have mitigated threats to water resources and management in recent years. Because of the geography and effort necessary to combat the lack of freshwater resources nearby, water is appropriately prioritized. However, more could be done to prevent future problems or solve current concerns within the city. Water promotional efforts and campaigns could provide the city with education on water saving techniques and provide more transparency between the administration and consumers. Installation of public water fountains could increase consumer trust with the water supply provided. Lastly, implementation of membrane bioreactor systems, or MBRs, could help mitigate the sewage pollution in surrounding surface waters. Investment in water transfer projects provides a high cost, quick solution to hold off water demand concerns for the near future, so now the administration can turn the agenda towards a long-term conservation and reuse perspective. Water conservation and smart usage would increase awareness, popularity, and suggest the new efforts the administration is taking towards more sustainable practices. Campaigns have been successful in 
the past, both in comparable cities, as well as Istanbul itself.

As part of a campaign movement towards conservation and sustainable practices with water, ISKI could implement a promotional prototype project of installing public water bottle filling stations around the city. While costly at first, these bottle filling stations could promote further consumption and trust in the city water network and its water quality that ISKI claims to provide.

\section{Finance}

\subsection{Function of the Finance Team}

The function of the finance team in this project was to collect data surrounding the funding, both foreign and domestic, of the urban development projects that are components of the 5-Year Environmental Plan (2021-2025) for Istanbul proposed here. The finance team evaluated the proposed projects of the poverty alleviation, transportation, industry, sewage and solid waste, energy, and water sectoral teams. In order to implement the proposed projects, the finance team determined a projected 5-year budget. This 5-year budget for Istanbul is presented in addition to bank assistance, foreign aid, foreign direct investment, and Turkey's national budget. Although Turkey has been somewhat effective in curbing the spread of the COVID-19 virus, the economy has still been vulnerable to the related global downturn. The pandemic reached Istanbul in March 2020 and subsequently curbed the growth of the nation's economy. The World Bank Group has detailed the deficit of Turkey in 2020, which has been significantly affected by diminished tourism. Fallen global demand also resulted in a dramatic decrease in trade, while COVID-19 led to a decline in employment as well. These difficulties also put Turkish citizens at risk of an increasing poverty rate. Due to government spending because of these factors, there is predicted to be an emphasis on plans concerning public health and poverty alleviation (World Bank Group, 2020).

\subsection{Process}

The process of the finance team began by extensively researching the economic realities of Istanbul and Turkey at large. Through this research, budget trends were determined by averaging the percent budget increase of Istanbul over the last three years. (2016-2017, 2017-2018, 2019-2020). This average percent increase was projected for a budget of 5 years. Once this budget was calculated, the detailed proposals of the transportation, sewage and sanitation, water, industry, energy, and poverty alleviation sectors were introduced. These proposals included the cost and scheduled beginning and end dates of each project. The finance team then estimated what projects could be realized, depending on the yearly budget.

Factors considered in determining the funds that would be available for the sectoral projects include government income, government spending, Gross Do- 
mestic Product, government tax revenue, the banking system, foreign aid and foreign investment. The trends in each were explored and assumptions made about future growth.

\subsection{Findings}

In conclusion, the finance team has determined that the Istanbul government budget from 2021 to 2025 is able to fund the projects that have been proposed here for each year of the 5-year environmental planning period. Additionally, foreign investment and foreign aid can provide funding to support the projects that have been developed by the 6 sectoral teams. The banking system of Istanbul is also healthy enough to enable investment in these projects.

\section{Conclusion}

The intent of this project was to bring the contemporary thinking and practice of Urban Environmental Management to the solution of real problems in Istanbul, Turkey, one of the largest agglomerations in Europe and the $5^{\text {th }}$ largest city in the world

(https://www.worldpopulationreview.com/world-cities/istanbul-population).

The objective was to replicate as much as possible the conditions under which a team of expatriate consultants would operate in this context so that they could develop ideas and procedures that fit the circumstances they would likely confront as professional planners working on such projects for international development banks, multilateral donors in the United Nations system, as well as the numerous bilateral donors of the developed countries. Consulting firms operating internationally on projects these institutions, agencies and countries fund come not only from the donor countries, but increasingly from countries such as Brazil, India, China and Korea as well, and the staffs of experts they provide often come from a variety of countries (Edelman, 2014; Edelman, 2018). In this working environment, it was instructive for the students to formulate a 5-year plan of solutions to the environmental problems and issues they faced rather than be told how to deal with them. They explored government data from Istanbul and Turkey and consulted a professor in Istanbul, as well as looked at academic articles and the Turkish press. This expanded their analytical skills and taught them how to utilize the limited knowledge and resources available to come up with implementable solutions for the benefit of the people of Istanbul. They learned that such skills are transferable to other projects, and they gained a greater appreciation of the skill set that they are developing as planners (Edelman, 2016). Bringing the reality of development to the classroom and asking students to confront it gives them an appreciation of professional practice that the study of theory alone does not (Edelman, 2015). Consequently, this project has attempted not only to expand the education of graduate students, but also to provide a meaningful contribution to planning pedagogy (Edelman, 2019). 


\section{Conflicts of Interest}

The author declares no conflicts of interest regarding the publication of this paper.

\section{References}

Berkun, M., Aras, E., \& Nemlioglu, S. (2005). Disposal of Solid Waste in Istanbul and along the Black Sea Coast of Turkey. Waste Management, 25, 847-855.

https://doi.org/10.1016/j.wasman.2005.04.004

Bike Cleveland (2018). https://www.bikecleveland.org

BikePGH (2018). https://bikepgh.org

Bilgic, T. (2019). Turkey Presents Prototypes in \$3.7 Billion Car Project. http://www.bloomberg.com/news/articles/2019-12-27/turkey-unveils-details-of-3-7-bill ion-domestic-car-project

Conexio Energy (n.d.). Renewable Energy Development of Turkey. https://conexioenergy.com/renewable-energy-development-of-turkey/

Courrier International (2020). Canal Istanbul: New Landmark Project of Turkey. https://eraiturkey.com/news/canal-istanbul-new-landmark-project-of-turkey/

Daily Sabah (2014). Istanbul Highest Consumer of Electricity. https://www.dailysabah.com/energy/2014/11/12/istanbul-highest-consumer-of-electrici ty

Easton, P. (2017). Istanbul: City of Water. https://www.revolve.media/istanbul-city-of-water

Edelman, D. J. (2014). Managing the Urban Environment-Mysore, India. Saarbrücken: LAP LAMBERT Academic Publishing.

Edelman, D. J. (2015). Managing the Urban Environment-Lagos, Nigeria. Saarbrücken: LAP LAMBERT Academic Publishing.

Edelman, D. J. (2016). Managing the Urban Environment-Manila, the Philippines. Saarbrücken: LAP LAMBERT Academic Publishing.

Edelman, D. J. (2018). Managing the Urban Environment of Lima, Peru. Advances in Applied Sociology, 8, 233-284. https://doi.org/10.4236/aasoci.2018.83014

Edelman, D. J. (2019). Managing the Urban Environment of Santo Domingo, the Dominican Republic. Current Urban Studies, 7, 76-142. https://doi.org/10.4236/cus.2019.71005

Edelman, D. J. (2021). Managing the Urban Environment-Istanbul, Turkey. Saarbrücken: LAP LAMBERT Academic Publishing.

Edelman, D. J., \& Gunawan, D. (2020). Managing the Urban Environment of Jakarta, Indonesia. Current Urban Studies, 8, 57-106. https://doi.org/10.4236/cus.2020.81003

Edelman, D. J., Schuster, M., \& Said, J. (2017). Urban Environmental Management in Latin America, 1970-2017. Current Urban Studies, 5, 305-331.

https://doi.org/10.4236/cus.2017.53017

Enerdata (2020). Turkey Energy Information. https://www.enerdata.net/estore/energy-market/turkey.html

Erai Turkey (2020). Textile Industry in Turkey in 2020. http://eraiturkey.com/news/textile-industry-in-turkey-in-2020/

Films Media Group (2013). Istanbul: Urban Future.

Fox, T. (2020). Erdoğan’s 'Crazy Project': New Istanbul Canal to Link Black and Marmara 
Seas.

https://www.theguardian.com/environment/2020/feb/17/canal-istanbul-erdogans-craz

y-plan-to-plot-route-between-black-and-marmara-seas

Güven, S. (2017). Turkey's Automotive Industry on Steady Growth Track.

http://www.wardsauto.com/industry/turkey-s-automotive-industry-steady-growth-trac $\underline{\mathrm{k}}$

Hennig, M. (2011). Sustainable Urban Mobility: The Example of Istanbul. Case No. 3. GIZ. Transport Policy Advisory Services. Bonn: Federal Ministry for Economic Cooperation and Development.

https://f.hypotheses.org/wp-content/blogs.dir/423/files/2013/03/2011-08-CS03 Istanbu 1 dtp300.pdf

Iglesias, R., Simon, P., Moragas, L., Arce A., \& Rodriguez-Roda, I. (2017). Cost Comparison of Full-Scale Water Reclamation Technologies with an Emphasis on Membrane Bioreactors. Water Science \& Technology, 75, 2562-2570.

https://doi.org/10.2166/wst.2017.132

International Energy Agency (IEA) (2020). Data and Statistics.

https://www.iea.org/data-and-statistics?country=WORLD

ISKI (2020). Istanbul Water and Sewage Administration-Istanbul Metropolitan Municipality.

https://www.iski.istanbul/web/en-US/kurumsal/iski-hakkinda/history-of-water-manag ement-in-istanbul

Istanbul Metropolitan Municipality (2018). Annual Report 2018.

https://www.ibb.istanbul/en/SitePage/Index/212

İstanbul Ticaret Gazetesi (2020). https://www.itohaber.com

Jacques, D. (2019). 10 Facts about Poverty in Istanbul.

https://borgenproject.org/10-facts-about-poverty-in-istanbul/

Lehtinen, A. (2012). Cleaning Up the Bosphorus.

https://theecologist.org/2012/oct/22/cleaning-bosphorus

Nas, B., \& Bayram, A. (2008). Municipal Solid Waste Characteristics and Management in Gümüşhane, Turkey. Waste Management, 28, 2435-2442.

https://doi.org/10.1016/j.wasman.2007.09.039

Ozturk, I., \& Dursun, A. (2015). Water and Wastewater Management in Istanbul. UNESCO HQ International Conference on Water, Megacities and Global Change, Paris, 1-4 December 2015, 1-26.

https://www.researchgate.net/publication/286354519 WATER AND WASTEWATER MANAGEMENT IN ISTANBUL

Ozturk, I., Gokhan, C., \& Karim, A. (2017). Assessing the Water-Resources Potential of Istanbul by Using a Soil and Water Assessment Tool (SWAT) Hydrological Model. Water, 9, 814. https://doi.org/10.3390/w9100814

https://www.researchgate.net/publication/320602160 Assessing the Water-Resources Potential of Istanbul by Using a Soil and Water Assessment Tool SWAT Hydr ological Model

The Times Tribune (1974). One-Time Capital of 3 Empires: Wealth of Antiquity in Istanbul. Sun Page 20. http://www.newspapers.com

TripAdvisor (2020). http://tripadvisor.com.

TRUiC (2020). How to Start a Community Garden.

https://howtostartanllc.com/business-ideas/community-garden 
Türkoğlu, H. (2020). Urban Development in Istanbul. Cincinnati, OH: University of Cincinnati.

TURKSTAT (2019). https://www.tuik.gov.tr

van Leeuwen, K., \& Sjerps, R. (2016). Istanbul: The Challenges of Integrated Water Resources Management in Europe's Megacity. Environment, Development and Sustainability, 18, 1-17. https://doi.org/10.1007/s10668-015-9636-Z

Watershare (2020). The Watershare Concept. https://www.watershare.eu/watershare-concept/

World Bank Group (2020). Turkey Overview.

https://www.worldbank.org/en/search?q=http\%3A\%2F\%2Fworldbank.org\%2Fturkey\% 2Foverview\%2Feconomy

World Population Review (2020). Turkey Population 2020 (Live). https://www.worldpopulationreview.com/countries/turkey-population

Zorlu Holding (n.d.). Consumer Electronics, White Goods and Information Technologies. 